\title{
IMPLEMENTASI PENDIDIKAN KARAKTER DALAM MEMBENTUK PERILAKU SOSIAL DAN KEAGAMAAN SISWA
}

\author{
Anis Fauzi \\ Institut Agama Islam Negeri Sultan Maulana Hasanuddin Banten \\ Jl. Jenderal Sudirman No. 30 Kota Serang Provinsi Banten, 42118 \\ Email: Jantera_Anis@yahoo.com \\ Mujibudda'wah \\ Sekolah Menengah Pertama Negeri 2 Cimanuk-Pandeglang \\ Jl. Tb. A. Ghozali km. 04 Cibaru Cimanuk Pandeglang, 42271 \\ Email: mujibudawahspd@gmail.com
}

\begin{abstract}
Abstrak:
Penelitian ini bertujuan mengetahui program dan implementasi Pendidikan Karakter dalam membentuk Perilaku Sosial dan Keagamaan Siswa di SMP Negeri 1 Cimanuk Kabupaten Pandeglang. Metode penelitian deskriptif kualitatif digunakan untuk menggambarkan fenomena-fenomena yang ada saat ini mengenai Implementasi Pendidikan Karakter Dalam Membentuk Perilaku Sosial dan Keagamaan Siswa studi di SMP Negeri 1 Cimanuk Kabupaten Pandeglang. Hasil penelitian ini adalah (1) Program pendidikan karakter merupakan bagian dari pembinaan siswa yang telah diprogramkan; (2) Implementasi pendidikan karakter berupa membaca do'a bersama, membaca surat-surat pendek; (3) Siswa suka mengobrol, saling membantu, menengok siswa yang sakit, suka bersalam-salaman, melaksanakan piket dan suka bekerja sama.
\end{abstract}

\begin{abstract}
:
This research aims at finding character educationa program and its implementation in building social and religious character at the students of SMPN 1 Cimanuk Kabupaten Pandeglang. It used qualitative descriptive which is used to describe current phenomenon about the implementation of character education in building social and religious character of at the students of SMPN 1 Cimanuk Kabupaten Pandeglang. The result of the research shows that (1) charcter education program is a part of students building program; (2) the implementation of character education such as reciting prayer together, reciting short Surah; (3) students like to interact with other people, help each others, visit sick students, shake hand, do the picket, and cooperate.
\end{abstract}

$$
\begin{gathered}
\text { Kata Kunci: } \\
\text { Implementasi, pendidikan karakter, perilaku keagaman, siswa. }
\end{gathered}
$$

MANUSIA yang diserahi fungsi pengelolaan bumi ini berusaha bagaimana dapat menjalankan fungsi ini dengan sebaik-baiknya menggali dan mengembangkan potensi yang ada pada dirinya termasuk mengkaji dirinya sendiri dengan segala aspeknya, ${ }^{1}$ baik aspek jasmani dan rohani, serta aspek kognitif, afektif dan psikomotoriknya.

Pada hakekatnya manusia mempunyai potensi fujur dan taqwa. Ketaqwaan yang dimiliki manusia, akan melahirkan karakter yang baik. Manusia yang mempunyai karakter baik, apabila diberi amanah menjadi pemimpin sebuah negara, maka 
negara tersebut akan dikelola menjadi negara yang adil dan makmur. Sebaliknya, jika manusia mempunyai karakter buruk, maka tunggulah kehancuran. Menyadari begitu pentingnya karakter bangsa yang harus dimiliki manusia, para founding father (bapak pendiri bangsa) menyatakan bahwa tiga tantangan besar yang akan dihadapi, perta$m a$, mendirikan negara yang bersatu dan berdaulat. Kedua, membangun bangsa. Ketiga, pembangunan karakter bangsa (nation and character building). ${ }^{2}$ Ketiga tantangan tersebut dalam pelaksanaannya membutuhkan kerjasama semua komponen baik pemerintah maupun setiap warga negara. Dari ketiga hal tersebut yang sekarang menjadi sorotan publik adalah membangun karakter bangsa.

Alasan perlunya membangun karakter bangsa yakni keberadaan karakter bangsa merupakan pondasi. Bangsa yang memiliki karakter kuat, mampu menjadikan dirinya sebagai bangsa yang bermartabat dan disegani oleh bangsa-bangsa lain. Oleh karena itu, menjadi bangsa yang berkarakter adalah tujuan dari pembangunan karakter bangsa. ${ }^{3}$ Bangsa yang berkarakter adalah bangsa yang memiliki cirri-ciri di antaranya: memiliki semangat kebangsaan yang tinggi, cinta tanah air, disiplin dan bertanggung jawab, toleransi dan menghargai perbedaan, cinta damai, peduli sosial dan peduli lingkungan.

Pendidikan karakter, sejak dari pendidikan keluarga dan sekolah dasar hingga sekolah menengah sampai perguruan tinggi diajarkan melalui bidang studi Pendidikan Agama dan Umum maupun pada kegiatan ekstra-kurikuler, tercermin pada perilaku sosial dan keagamaan yang merupakan implementasi dari pendidikan karakter siswa. Hal ini ditandai dengan fenomena siswa dapat bergaul dengan baik, peduli terhadap teman, membantu kebutuhan siswa lain, berperilaku Islami, suka beribadah dalam pergaulan sehari-hari di lingkungan sekolah maupun di masyarakatnya.

Namun demikian, pada kehidupan sehari-hari di sekolah maupun di masyarakat masih banyak siswa yang melakukan perbuatan yang menyimpang, seperti membantah kepada orang tua, tidak patuh kepada guru, melanggar tata tertib sekolah, banyak siswa yang bolos, melakukan kenakalan remaja, terlibat pergaulan bebas dan terjerumus ke dalam penyalahgunaan narkoba. Penyalahgunaan narkotika yang disiarkan oleh salah satu stasiun televisi, Polda Jawa Barat menggerebek rumah kosan di J1. Pajajaran Bandung dan menemukan 55 butir pil ekstasi dan brownies berisi ganja, juga di Makasar, Sulawesi Selatan ditemukan Ganja Kering yang siap diedarkan dari para pengedar jaringan Internasional. ${ }^{4}$ Untuk diedarkan kepada para remaja dan anak-anak.

Dalam perilaku keagamaanpun masih banyak siswa yang tidak mendirikan salat lima waktu (shalat fardhu), tidak melaksanakan shalat secara berjamaah, banyak siswa yang tidak melaksanakan shalat jum'at, banyak siswa yang tidak belajar mengaji dan lain-lain. ${ }^{5}$

Dari kasus di SMP Negeri 1 Cimanuk Kabupaten Pandeglang Provinsi Banten menarik untuk diteliti, dalam hal ini untuk diketahui presiminary research, apakah benar pendidikan karakter yang kurang maksimal menjadi penyebab terjadinya kenakalan siswa. Selain itu penulis ingin mengangkat perilaku sosial dan keagamaan siswa. 
Pendidikan karakter mempunyai tujuan penanaman nilai dalam diri siswa dan pembaruan tata kehidupan bersama yang lebih menghargai kebebasan individu. Selain itu meningkatkan mutu penyelenggaraan dan hasil pendidikan di sekolah yang mengarah pada pencapaian pembentukan karakter dan akhlak mulia peserta didik secara utuh, terpadu dan seimbang sesuai dengan standar kompetensi lulusan. ${ }^{6}$

Sedangkan tujuan pendidikan karakter yang diharapkan Kementerian Pendidikan Nasional 7 adalah:

a. Mengembangkan potensi qalbu/nurani/afektif peserta didik sebagai manusia dan warga negara yang memiliki nilai-nilai budaya dan karakter bangsa;

b. Mengembangkan kebiasaan dan perilaku peserta didik yang teruji dan sejalan dengan nilai-nilai universal dan tradisi budaya bangsa yang religius;

c. Menanamkan jiwa kepemimpinan dan tanggung jawab peserta didik sebagai generasi penerus bangsa;

d. Mengembangkan kemampuan peserta didik menjadi manusia yang mandiri, kreatif, berwawasan kebangsaan; dan

e. Mengembangkan lingkungan kehidupan sekolah sebagai lingkungan belajar yang aman, jujur, penuh kreativitas dan persahabatan, serta rasa kebangsaan yang tinggi dan penuh kekuatan (dignity).

Karakter berasal dari nilai tentang sesuatu. Suatu karakter melekat dengan nilai dari perilaku seseorang. Karenanya tidak ada perilaku anak yang tidak bebas dari nilai. Dalam kehidupan manusia, begitu banyak nilai yang ada di dunia ini, sejak dahulu sampai sekarang. ${ }^{8}$ Nilai-nilai pendidikan karakter yang dikembangkan Kementerian Pendidikan ada delapan belas (18) karakter. Nilai-nilai tersebut bersumber dari agama, pancasila, budaya, dan tujuan pendidikan nasional. Adapun delapan belas nilai tersebut yaitu: religius, jujur, toleransi, disiplin, kerja keras, kreatif, mandiri, demokrasi, rasa ingin tahu, semangat kebangsaan, cinta tanah air, menghargai prestasi, bersahabat/komunikatif, cinta damai, gemar membaca, peduli lingkungan, peduli sosial, dan tanggung jawab. ${ }^{9}$

Berdasarkan latar belakang di atas, dapat dirumuskan permasalahan pokok yang akan diteliti, yaitu: bagaimanakah implementasi pendidikan karakter dalam membentuk perilaku sosial dan keagamaan siswa di SMP Negeri 1 Cimanuk Kabupaten Pandeglang?

Adapun tujuan penelitian ini adalah untuk menegetahui (1) Program Pendidikan Karakter di SMP Negeri 1 Cimanuk, (2) Implementasi Program Pendidikan Karakter siswa di SMP Negeri 1 Cimanuk, dan (3) Program Pendidikan Karakter dalam Membentuk Perilaku Sosial dan Keagamaan Siswa SMP Negeri 1 Cimanuk Kabupaten pandeglang.

\section{TINJAUAN PUSTAKA}

Ada tiga hal yang perlu ditekankan dalam pendidikan karakter. Pertama, pendidikan karakter berlaku untuk semua siswa tanpa ada satupun yang tertinggal. Kesempatan yang sama adalah prinsip dasar pendidikan yang harus diatur oleh pemerintah. Tujuan utama dari pendidikan dasar terletak pada dasar yang kuat untuk me- 
ningkatkan kualitas bangsa sebagai dasar untuk menyiapkan setiap anak untuk pendidikan di masa depan dan kehidupan sosialnya. Kedua, pendidikan karakter didesain untuk mendukung semua pengembangan siswa, sebagai inti pendidikan prinsip bangsa. Pendidikan karakter menentukan seimbangnya komposisi sifat atau karakter yang dibangun melalui pendidikan. Baik secara fisiologis, psikologis, ideologis maupun budaya. Pendidikan karakter bermakna menanamkan nilai moral yang tinggi, fisik dan mental yanh sehat, kaya akan pengetahuan, keterampilan khusus, pemikiran yang terbuka dan kemampuan praktis yang kuat pada anak. Ketiga, pendidikan karakter mendukung pengembangan individu siswa yang sehat dan memperhatikan perbedaan kemampuan individu dan menghendaki tatakrama sosial. ${ }^{10}$

Untuk memperjelas kedudukan penelitian yang hendak dilakukan ini, perlu dilakukan telaah terhadap hasil-hasil penelitian terdahulu yang ada relevansinya dengan masalah yang hendak diteliti. Adapun penelitian-penelitian terdahulu yang telah ditelaah adalah sebagai berikut:

1. Penelitian Thomas Lickona; $2012^{11}$ dalam bentuk buku: Education For Character, merupakan buku hasil penelitian tentang pendidikan dalam membentuk karakter dan moral, serta bagaimana sekolah dapat mengajarkan sikap hormat dan tanggung jawab serta pengetahuan tentang nilai-nilai karakter yang baik. Perbedaannya dengan penelitian ini adalah bahwa Implementasi Pendidikan karakter dalam Membentuk Perilaku Sosial dan Keagamaan Siswa, lebih menekankan pada dampak pelaksanaan pendidikan karakter dalam meningkatkan perilaku sosial dan keagamaan, sedangkan buku Educating for Character membahas dan meneliti secara umum tentang bagaimana sekolah dapat mengajarkan nilai-nilai karakter dan moral secara umum.

2. Penelitian I.B. Wirawan, ${ }^{12}$ dalam bentuk buku; Teori-teori Sosial dalam Tiga Paradigma, Fakta Sosial, Definisi Sosial dan Perilaku Sosial, membahas dan meneliti tentang Paradigma Fakta Sosial, Paradigma Definisi Sosial dan Paradigma Perilaku Sosial secara umum, sedangkan penelitian ini membahas tentang Implementasi Pendidikan Karakter dalam Meningkatkan Perilaku Sosial dan Keagamaan.

3. Penelitian Moh. Dloni (2012) ${ }^{13}$ dalam bentuk tesis tentang Dampak Lingkungan Sosial Kemasyarakatan terhadap Perilaku Keagamaan Siswa di SMP N 2 Gabus Kabupaten Pati". Penelitain Moh. Dloni penekanannya pada dampak lingkungan sosial terhadap perilaku keagamaan saja, sedangkan penelitian ini konsentrasinya pada pelaksanaan pendidikan karakter dalam meningkatkan perilaku sosial dan keagamaan siswa, jadi bukan hanya perilaku keagamaan.

4. Penelitian Hery Nugraha (2012) ${ }^{14}$ dalam bentuk tesis tentang Implementasi Pendidikan Karakter dalam Pendidikan Agama Islam di SMA Negeri 3 Semarang; persamaannya dengan penelitian ini pada implementasi pendidikan karakter, sedangkan perbedaannya, Tesis Heri Nugraha, penekanannya dalam Pendidikan Agama Islam di SMA Negeri 3 Semarang, sedangkan penekanan penelitian ini pada implementasi pendidikan karakter dalam membentuk Perilaku Sosial dan Keagamaan Siswa SMP Negeri 1 Cimanuk kabupaten Pandeglang. 
5. Tulisan RA. Yusriana K (2013) $)^{15}$ dalam bentuk jurnal tentang Perilaku Sosial Remaja dalam Memanfaatkan Ruang Publik Perkotaan, (Studi Kasus Pemanfaatan Taman Kota Benteng Rotterdam Makassar), persamaannya dalam perilaku sosial remaja; Perbedaannya penelitian ini tentang pelaksanaan pendidikan karakter dalam meningkatkan perilaku sosial dan keagamaan siswa di SMP Negeri 1 Cimanuk Kabupaten Pandeglang. Sedangkan tulisan RA Yusriana tentang pemanfaatan ruang publik perkotaan dalam hal ini Taman Kota Benteng Rotterdam Makasar.

Pendidikan karakter dimaknai dengan suatu sistem penanaman nilai-nilai karakter kepada warga sekolah yang meliputi komponen pengetahuan, kesadaran atau keimanan, dan tindakan untuk melaksanakan nilai-nilai tersebut baik terhadap Tuhan yang Maha Esa, diri sendiri, sesama, lingkungan, maupun kebangsaan sehingga menjadi manusia insan kamil.

Perilaku sosial adalah aktifitas fisik dan psikis seseorang terhadap orang lain atau sebaliknya dalam rangka memenuhi diri atau orang lain yang sesuai dengan tuntutan sosial.

Perilaku Keagamaan yaitu segala tindakan, perbuatan atau ucapan yang dilakukan seseorang sedangkan perbuatan atau tindakan serta ucapan tadi ada keterkaitan dengan agama, semuanya dilakukan karena adanya kepercayaan kepada Tuhan dengan ajaran, kebaktian dan kewajiban-kewajiban yang bertalian dengan kepercayaan.

Keterkaitan pendidikan karakter dengan perilaku sosial dan perilaku keagamaan, dapat dilihat dalam kerangka pemikiran di bawah ini.

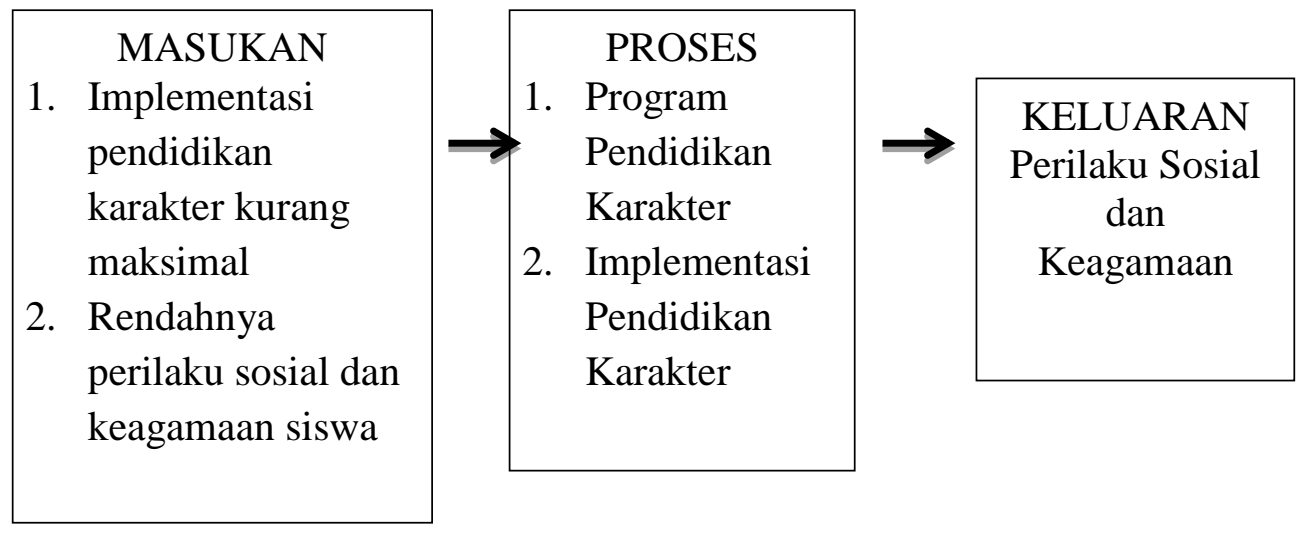

\section{METODE PENELITIAN}

Metode penelitian yang digunakan adalah metode deskriptif kualitatif. Penelitian deskriptif ditujukan untuk menggambarkan fenomena-fenomena yang ada, yang berlangsung saat ini atau saat yang lampau. ${ }^{16}$ Alasan menggunakan metode deskriptif karena untuk mendapatkan gambaran sistematis, faktual dan akurat mengenai Implementasi Pendidikan Karakter Dalam Membentuk Perilaku Sosial dan Keagamaan Siswa studi di SMP Negeri 1 Cimanuk Kabupaten Pandeglang.

Tempat penelitian ini bertempat di SMP Negeri 1 Cimanuk kabupaten Pandeg- 
lang Jl. Stasiun Kadukacang KM. 02 Batubantar Cimanuk 42271. Dengan alasan SMP Negeri 1 Cimanuk sudah melaksanakan kurikulum berkarakter dalam kegiatan belajar mengajar maupun dalam kegiatan ekstrakurikuler.

Dalam penelitian kualitatif, teknik sampling yang sering digunakan adalah purposive sampling, dan snowball sampling. Purposive sampling adalah teknik pengambilan sampel sumber data dengan pertimbangan tertentu. Pertimbangan tertentu ini, misalnya orang tersebut yang dianggap paling tahu tentang apa yang kita harapkan, atau mungkin dia sebagai penguasa sehingga akan memudahkan peneliti menjelajahi objek/situasi sosial yang diteliti. Snowball sampling adalah teknik pengambilan sampel sumber data, yang pada awalnya jumlahnya sedikit, lama-lama menjadi besar. Hal ini dilakukan karena dari jumlah sumber data yang sedikit itu tersebut belum mampu memberikan data yang lengkap, maka mencari orang lain lagi yang dapat digunakan sebagai sumber data akan semakin besar, seperti bola salju yang menggelinding, lama-lama menjadi besar. ${ }^{17}$

Sampel dalam penelitian kualitatif bukan dinamakan responden, tetapi sebagai narasumber, atau partisipan, informan, teman dan guru dalam penelitian. Sampel dalam penelitian kualitatif, juga bukan disebut sampel statistik, tetapi sampel teori, karena tujuan penelitian kualitatif adalah untuk menghasilkan teori. Sampel dalam penelitian kualitatif disebut juga sebagai sampel konstruktif, karena dengan sumber data dari sampel itu dapat dikonstruksikan fenomena yang semula masih belum jelas. ${ }^{18}$

Dari uraian di atas, yang dijadikan subjek penelitain adalah kepala sekolah, guru, TU dan siswa - siswi SMP Negeri 1 Cimanuk Kabupaten Pandeglang. Dalam penelitian ini data yang akan diteliti, yaitu data kualitatif. Data kualitatif akan diteliti dengan tehnik observasi, wawancara, dokumentasi dan analisis dengan analisis logika. Fokus penelitian pada implementasi pendidikan karakter dalam membentuk perilaku sosial dan keagamaan siswa SMP Negeri 1 Cimanuk Kabupaten Pandeglang.

Peneliti kualitatif sebagai sumber human instrument, berfungsi menetapkan fokus penelitian, memilih informan sebagai sumber data, menetapkan pengumpulan data, menilai kualitas data, analisis data, menafsirkan data dan membuat simpulan atas temuannya. ${ }^{19}$

Tujuan utama penelitian ini adalah untuk menemukan prinsip-prinsip universal dari data yang telah terkumpul serta telah dianalisis dan hasilnya ternyata dapat diolah semuanya, data yang telah terkumpul, yang diperoleh melalui proses elaborasi dari berbagai sumber, diklasifikasikan, disusun sesuai dengan kategori data yang diperlukan untuk pembahasan rumusan masalah yang ditemukan kemudian dianalisis dengan menggunakan analisis data kualitatif. Ini merupakan hal yang wajar, sebab analisis data dalam penelitian kualitatif berbeda dengan analisis data penelitian lain. ${ }^{20}$

Menurut Patton, analisis data adalah proses yang membawa bagaimana data diatur, mengorganisasikan apa yang ada ke dalam sebuah pola, kategori, dan unit deskripsi data. Penafsiran melibatkan upaya penyertaan makna dan signifikasi ke analisis, melakukan penjelasan pola deskriptif, dan mencari hubungan dan keterkaitan di antara dimensi deskriptif. ${ }^{21}$ 
Analisis data kualitatif adalah proses kreatif. Tidak ada rumusan masalah seperti dalam ilmu statistik. Hal ini adalah proses yang menuntut kekerasan intelektual dan banyak sekali kerja keras dan pantang menyerah. Karena orang yang berbeda menangani kreativitas usaha intelektualnya masing-masing yang sungguh-sungguh dan kerja keras dalam cara yang berbeda, tidak ada satu cara yang benar tentang mengorganisasi, menganalisis, dan menafsirkan data kualitatif. Apa yang diikuti adalah saran untuk arahan dasar analisis kualitatif dari pada merupakan aturan ketat dan suatu prosedur. ${ }^{22}$

Analisis data yang digunakan adalah analisis deskriptif kualitatif. Data yang diperoleh dari wawancara kemudian disusun dalam catatan lengkap setelah didukung oleh hasil observasi dan dokumentasi. Dengan demikian, data yang diperoleh dari hasil penelitian ini adalah data hasil observasi, wawancara dan studi dokumentasi. Berkaitan dengan hal tersebut, pengolahan dan analisis data dalam penelitian ini dilakukan melalui empat alur kegiatan, seperti yang dikemukakan Miles dan Huberman berikut ini.

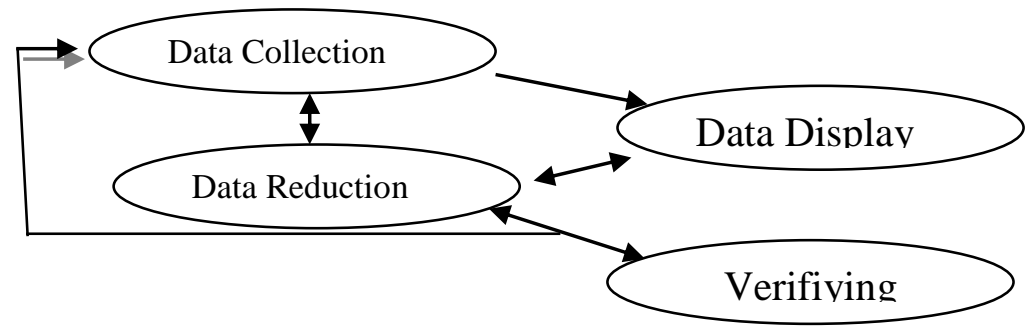

Komponen dalam analisis data (interactive model) $)^{23}$

\section{HASIL PENELITIAN DAN PEMBAHASAN}

\section{Program Pendidikan Karakter di SMP Negeri 1 Cimanuk}

Kementrian Pendidikan Nasional telah menata pendidikan karakter di sekolah atau pada tataran mikro di era modern ini, yaitu:

1. Secara mikro pengembangan nilai/karakter dapat dibagi dalam empat pilar, yakni kegiatan belajar mengajar di kelas, kegiatan keseharian dalam bentuk budaya satuan pendidikan; kegiatan ko-kulikuler, serta kegiatan keseharian di rumah dan dalam masyarakat.

2. Dalam kegiatan belajar mengajar di kelas pengembangan nilai karakter dilaksanakan dengan menggunakan pendekatan terigtegrasi dalam semua mata pelajaran. Khusus, untuk mata pelajaran pendidikan agama dan pendidikan kewarganegaraan, karena memang misinya adalah mengembangkan nilai dan sikap maka pengembangan nilai/karakter dikembangkan sebagai dampak pembelajaran dan juga dampak pengiring. Sementara itu untuk mata pelajaran lainnya, yang secara formal memiliki misi utama selain pengembangan nilai/karakter, wajib dikembangkan kegiatan yang memiliki dampak pengiring berkembangnya nilai/karakter dalam diri peserta didik. 
3. Dalam lingkungan satuan pendidikan dikondisikan agar lingkungan fisik dan sosial-kultural satuan pendidikan memungkinkan para peserta didik bersama dengan warga satuan pendidikan lainnya terbiasa membangun kegiatan keseharian di satuan pendidikan yang mencerminkan perwujudan nilai/karakter.

4. Dalam ko-kulikuler, yakni kegiatan belajar di luar sekolah yang terkait langsung pada suatu materi dari suatu mata pelajaran, atau kegiatan ekstrakurikuler, yakni kegiatan satuan yang bersifat umum dan tidak terkait langsung pada suatu mata pelajaran tertentu, seperti kegiatan dokter kecil, Palang Merah Remaja (PMR), Pramuka, Pecinta Alam, dan lain-lain. Perlu dikembangkan pembiasaan dan penguatan dalam rangka pengembangan nilai/karakter.

5. Di lingkungan keluarga dan masyarakat diupayakan agar terjadi proses penguatan dari orang tua wali serta tokoh-tokoh masyarakat terhadap perilaku berkarakter mulia yang dikembangkan di satuan pendidikan menjadi kegiatan keseharian di rumah dan lingkungan masyarakat masing-masing. ${ }^{24}$

Secara diagramatik, pendidikan karakter pada tataran mikro tersebut digambarkan sebagai berikut:

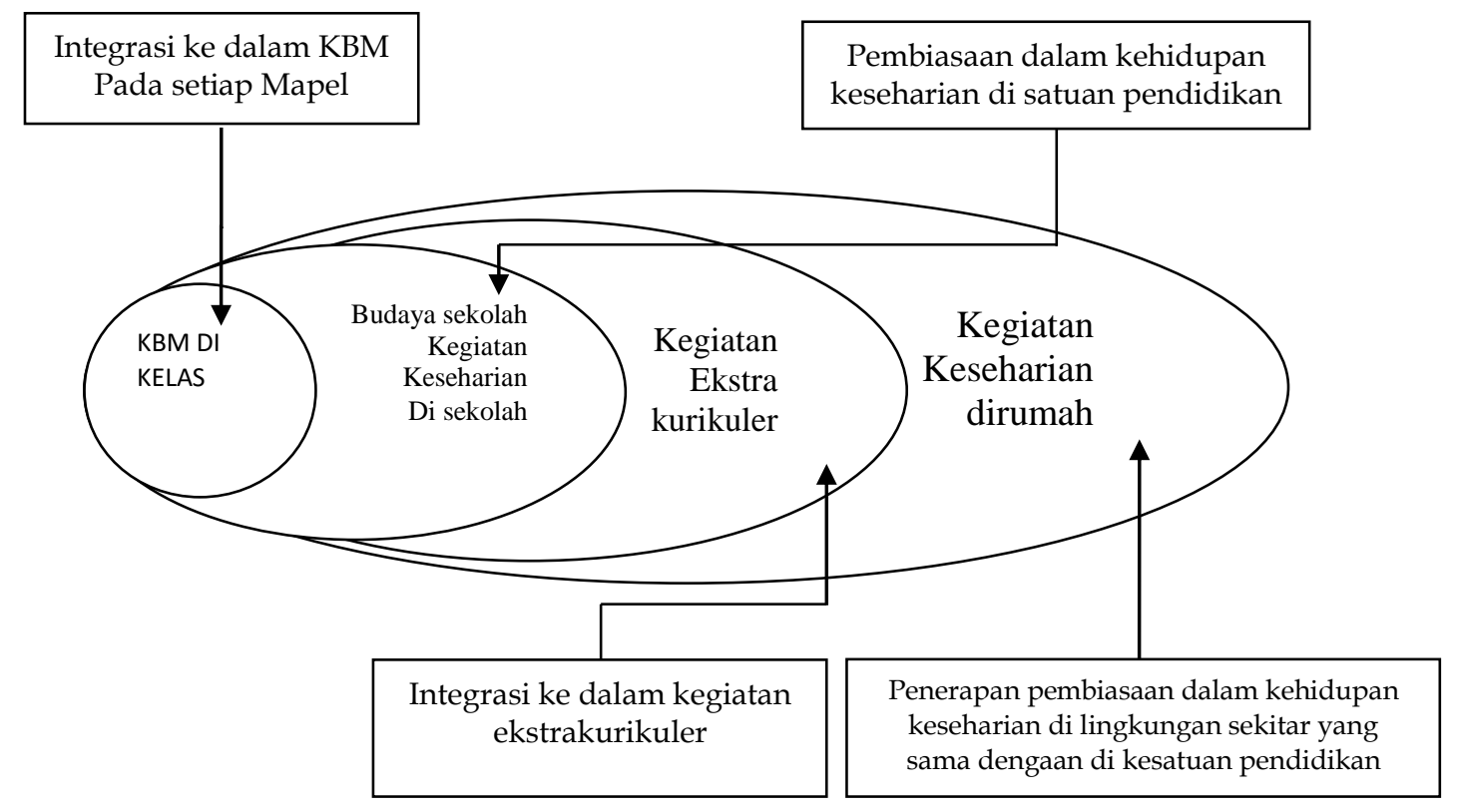

Sumber: Kementrian Koordinator Kesejahteraan Rakyat Republik Indonesia 201025

Penerapan manajemen sekolah berbasis karakter perlu untuk dibuat suatu program yang mengintegrasikan kurikulum dalam setiap kegiatan sekolah, di antaranya, sebagai berikut:

1. Mengintegrasikan nilai-nilai karakter pada keseluruhan kegiatan manajemen sekolah.

2. Mengintegrasikan nilai-nilai karakter pada keseluruhan kegiatan kinerja sekolah.

3. Mengintegrasikan nilai-nilai karakter pada keseluruhan kegiatan kinerja personil. 
4. Mengintegrasikan nilai-nilai karakter pada keseluruhan kegiatan layanan pendidikan.

5. Mengintegrasikan nilai-nilai karakter pada keseluruhan kegiatan pembelajaran.

Keberhasilan dalam proses pembentukan karakter siswa, akan ditentukan bukan oleh kekuatan proses pembelajaran, tetapi akan ditentukan oleh kekuatan manajemennya, yang mengandung pengertian bahwa mutu karakter siswa memiliki ketergantungan kuat terhadap kualitas manajemen sekolahnya. Hal ini disebabkan karena proses pembentukan karakter harus terintegrasi kedalam berbagai bentuk kegiatan sekolah. ${ }^{26}$

Dalam hal ini program pendidikan karakter di SMP Negeri 1 Cimanuk, berdasarkan hasil wawancara dengan kepala sekolah SMP Negeri 1 Cimanuk, Bapak Memed Hermanto, diketahui sebagai berikut:

1. Program pendidikan karakter secara umum sudah termuat di dalam kurikulum tingkat satuan pendidikan (KTSP) yang dikeluarkan oleh Kemendiknas dalam Penyusunan dan Pengembangan Silabus berkarakter dan Rencana Program Pembelajaran (RPP) berkarakter, pada setiap mata pelajaran dalam masing-masing bidang studi yang tertuang di dalam dokumen 1 (satu) SMP Negeri 1 Cimanuk.

2. Program pendidikan karakter secara khusus sering disampaikan oleh kepala sekolah SMP Negeri 1 Cimanuk dalam rapat-rapat kedinasan maupun rapat umum dengan dewan guru dan staf TU SMP Negeri 1 Cimanuk, mengingat hasil temuan kepala sekolah terhadap perilaku siswa SMP Negeri 1 Cimanuk masih banyak ditemukan penggunaan bahasa dalam pergaulan sehari-hari dengan sesama siswa mengucapkan kata-kata yang kurang baik, contohnya penggunaan bahasa secara kasar," pulpen aing aya nu maling", kata-kata yang kurang pantas, "dia mah kitu ieuh jelemana", emak aing lain, bapak aing lain", dan sebagainya; oleh sebab itu pentingnya pendidikan karakter diimplementasikan kepada siswa SMP Negeri 1 Cimanuk dalam suatu program kegiatan pembelajaran baik dalam intakurikuler maupun ekstrakurikuler.

3. Pendidikan karakter merupakan bagian dari pembinaan siswa SMP Negeri 1 Cimanuk yang telah diprogramkan dan dijadwalkan secara formal pada kegiatan pembinaan setiap hari jum'at pada pengajian jum'at taqwa dalam bidang keagamaan dan hari sabtu pada jam pertama dan kedua, selama 2 jam pelajaran dalam pembinaan siswa oleh maing-masing wali kelas dan kegiatan bakti sosial sekali setiap minggunya. ${ }^{27}$

\section{Implementasi Program Pendidikan Karakter di SMP Negeri 1 Cimanuk}

Sekolah merupakan sarana bagi pelaksanaan pendidikan karakter. pihak sekolah membutuhkan dukungan dari berbagai pihak untuk mengimplementasikan program pendidikan karakter, diantaranya pihak-pihak yang berkepentingan dan mempunyai wewenang itu seperti kepala sekolah, guru, dan staf TU untuk mengimplementasikan dalam suatu program manajemen sekolah berbasis karakter. Dalam hal ini sesuai dengan pengertian manajemen sekolah berbasis karakter. Manajemen sekolah dalam arti luas adalah suatu ilmu yang mempelajari penataan sumber daya yaitu 
sumber daya manusia, kurikulum atau sumber belajar dan fasilitas untuk mencapai tujuan pendidikan secara optimal dan menciftakan suasana yang baik bagi manusia, yang turut serta dalam pencapaian tujuan pendidikan yang disepakati. ${ }^{28}$

Sedangkan pengertian karakter, seperti yang disampaikan Gunarto ${ }^{29}$ bahwa “ Karakter merupakan nilai-nilai perilaku manusia yang berhubungan dengan Tuhan yang maha esa, diri sendiri, sesama manusia, lingkungan, dan kebangsaan yang terwujud dalam pikiran, sikap, perasaan, perkataan, dan perbuatan berdasarkan normanorma agama, budaya dan nilai kebangsaan yang diaktualisasikan dalam kehidupan sehari-hari menjadi suatu pembiasaan yang melekat.

Implementasi pendidikan karakter di SMP Negeri 1 Cimanuk, yang ditemukan dari hasil pengamatan peneliti pada pelaksanaan pengajian Jumtaq (Jum'at Taqwa) yang diselenggarakan setiap hari Jum'at pagi, dibimbing oleh dewan guru SMP Negeri 1 Cimanuk terutama Pembina Kerohanian Bapak Uum Jumhana, dan Pembina Kesiswaan Bapak Ojun Junaedi, ditemukan perilaku keagamaan sebagai berikut:

1. Pembacaan surat yasin bersama dibimbing oleh guru.

2. Pembacaan dzikir dan tasbih bersama-sama.

3. Tawashul yang dibimbing oleh guru dan Pembina kerohanian.

4. Pembacaan marhaba oleh siswa secara bergiliran per kelas setiap kegiatan pengajian Jum'at taqwa atau pada kegiatan keagamaan lainya.

5. Pembacaan shalawat bersama-sama.

6. Pembacaan do'a dipimpin oleh guru atau siswa yang ditugaskan.

7. Penampilan seni budaya Islam seperti group marawis dan qasidah pada waktuwaktu tertentu.

Selain kegiatan rutin tersebut di atas ada pula materi yang disampaikan seperti:

1. Ceramah Agama yang disampaikan oleh siswa.

2. Ceramah Agama yang disampaikan oleh guru pembimbing.

Materi-materinya berkaitan dengan peningkatan keimanan, ibadah maupun tentang perilaku keagamaan, seperti: shalat berjamaah, kewajiban menuntut ilmu berdasarkan Alquran dan Hadis, berbakti kepada orang tua, pergaulan sehari-hari baik di sekolah maupun di masyarakat harus sesuai dengan perilaku keagamaan yang baik. ${ }^{30}$

Implementasi pendidikan karakter di SMP Negeri 1 Cimanuk, hasil wawancara dengan guru PAI, yaitu Ibu Enok Solihah, sebagai berikut: “Program implementasi pendidikan karakter dalam perilaku keagamaan siswa yang dilaksanakan di SMP Negeri 1 Cimanuk", antara lain:

1. Membaca do'a bersama sebelum dan sesudah kegiatan belajar mengajar dipimpin oleh ketua kelas.

2. Membaca surat-surat pendek atau surat-surat pilihan 5 (lima) menit sebelum kegiatan belajar mengajar dimulai.

3. Membiasakan membaca juz'amma dan menghafalnya.

4. Apabila bertemu dengan guru atau siswa yang lain mengucapkan salam dalam rangka membiasakan ucapan salam. ${ }^{31}$ 
Implementasi pendidikan karakter dari narasumber atau informan guru mata pelajaran IPS Ibu Rina Mustikawati, terkait dengan program implementasi pendidikan karakter dalam perilaku sosial siswa SMP Negeri 1 Cimanuk, menyatakan sebagai berikut:

1. Peduli kepada siswa yang lain/kepada teman sekolah.

2. Menengok teman sekolah yang sakit.

3. Melakukan ta'ziyah apabila ada siswa/orang tua siswa yang meninggal dunia.

4. Interaksi dan berkomunikasi dengan siswa, guru, staf Tu dan kepala sekolah.

5. Melaksanakan K 3 (Kebersihan, Keindahan dan Ketertiban) bersama-sama.

6. Menanamkan cinta tanah air, semangat kebangsaan, disiplin, kerja sama dan tanggung jawab pada waktu pelaksanaan upacara kenaikan bendera pada setiap hari senin. ${ }^{32}$

Pelaksanaan pendidikan karakter di SMP Negeri 1 Cimanuk, tentang perilaku keagamaan, wawancara dengan siswa yang bernama Yulia Uswatun Hasanah kelas VIII C, sebagai berikut:

Apa saja implementasi pendidikan karakter yang diprogramkan dan dilaksanakan di SMP Negeri 1 Cimanuk?

Jawabannya:

1. Pengajian siswa, yang disebut pengajian Jum'at taqwa (Jumtaq) pada pagi hari setiap Jum'at.

2. Pelajaran yang disampaikan oleh guru-guru terkait tentang keagamaan.

3. Hafalan alqur'an pada juz'amma

4. Hafalan bacaan shalat, baik shalat sunah maupun shalat berjamaah. ${ }^{33}$

Hal ini sesuai dengan apa yang disampaikan Wakasek Kesiswaan Bapak Ojun Junaedi, ketika wawancara dengan peneliti di antaranya sebagai berikut:

Pendidikan karakter diimplemantasikan dalam pelaksanaan praktek ibadah, terutama bacaan-bacaan shalat, do'a-do'a sesudah shalat, siswa SMP Negeri 1 Cimanuk harus dapat melaksanakannya dengan baik karena manfaatnya untuk dilakukan siswa dalam kehidupan sehari-hari di rumah ataupun di masyarakat.

\section{Program Pendidikan Karakter dalam Membentuk Perilaku Sosial dan Keagamaan Siswa}

Program pendidikan karakter yang diimplemantasikan di SMP Negeri 1 Cimanuk dalam membentuk perilaku sosial dan keagamaan siswa, diantaranya berdasarkan hasil wawancara dan pengamatan pada kegiatan pembelajaran baik intrakurikuler maupun ekstrakurikuler sebagai berikut:

Berdasarkan hasil wawancara dengan siswi kelas IX A, yang bernama Atika tentang perilaku sosial dengan pertanyaan;

Perilaku sosial apa saja yang dilakukan oleh siswa SMP Negeri 1 Cimanuk dari program pendidikan karakter dalam membentuk perilaku sosial siswa di SMP Negeri 1 Cimanuk? 
Didapatkan data bahwa perilaku sosial yang suka dilakukan oleh siswa antara lain:

1. Suka mengobrol (berinteraksi dengan sesama siswa yang lain).

2. Saling membantu siswa yang lain/teman sekolah.

3. Suka menengok siswa yang sedang sakit.

4. Suka bersalam-salaman, baik dengan guru, kepala sekolah, staf TU ataupun sesama siswa. 34

Miftahul Huda siswa kelas IX E, mengatakan bahwa pendidikan karakter yang dilaksanakan di SMP Negeri 1 Cimanuk dalam membentuk perilaku sosial siswa di antaranya:

1. Setiap siswa melaksanakan piket sesuai dengan jadwalnya.

2. Setiap siswa bekerja sama dalam organisasi kesiswaan maupun dalam kegiatan sehari-hari di sekolah.

3. Kegiatan gotong-royong yang dilakukan pada hari-hari tertentu, misalnya hari sabtu pada kegiatan pembinaan yang dibimbing oleh wali kelas masing-masing. ${ }^{35}$

Program pendidikan karakter dalam membentuk perilaku keagamaan, didapatkan data hasil wawancara dengan siswa kelas VIII B, yang bernama Abi Madyan Andalusi yang mengatakan bahwa perilaku keagamaan yang suka dilakukan siswa SMP Negeri 1 Cimanuk, di antaranya:

1. Membaca do'a, sebelum dan sesudah kegiatan belajar mengajar.

2. Mengaji setiap hari Jum'at pada kegiatan pengajian Jum'at taqwa.

3. Bersalam-salaman dengan sesama siswa dan guru.

4. Membaca surat-surat pendek atau surat-surat pilihan. ${ }^{36}$

Pengamatan yang dilakukan peneliti pada kegiatan program kesiswaan dalam memilih pergantian ketua dan wakil ketua OSIS SMP Negeri 1 Cimanuk masa periode 2015-2016, di antanya, sebagai berikut:

1. Siswa belajar berorganisasi

2. Siswa bekerja sama dalam menentukan pengurus OSIS SMP Negeri 1 Cimanuk masa bakti 2015-2016.

3. Pembagian kerja dan tanggung jawab pengurus OSIS.

4. Siswa melaksanakan demokrasi dengan pemilihan langsung ketua dan wakil ketua OSIS.

5. Penampilan siswa berpendapat di depan umum dalam menyampaikan visi dan misi organisasi OSIS. ${ }^{37}$

Pengamatan peneliti tentang program pendidikan karakter dalam membentuk perilaku sosial dan keagamaan siswa SMP negeri 1 Cimanuk, sebagai berikut:

1. Siswa berorganisasi dan bekerja sama.

2. Siswa tolong menolong dengan sesama siswa yang lainnya.

3. Saling membantu dalam pekerjaan organisasi siswa.

4. Kekompakan dan kebersamaan dalam berorganisasi siswa.

5. Mentaati peraturan yang berlaku dan

6. Menjalankan kewajiban siswa. ${ }^{38}$ 


\section{KESIMPULAN}

Berdasarkan uraian-uraian di atas, selain uraian pendahuluan dan kajian teoritis tentang pendidikan karakter, perilaku sosial dan keagamaan, dapat penulis simpulkan sebagai berikut:

1. Program pendidikan karakter secara umum sudah termuat di dalam kurikulum tingkat satuan pendidikan (KTSP) yang dikeluarkan oleh Kemendiknas dalam Penyusunan dan Pengembangan Silabus berkarakter dan Rencana Program Pembelajaran (RPP) berkarakter, pada setiap mata pelajaran dalam masing-masing bidang studi yang tertuang di dalam dokumen 1 (satu) SMP Negeri 1 Cimanuk. Program pendidikan karakter secara khusus sering disampaikan oleh kepala sekolah SMP Negeri 1 Cimanuk dalam rapat-rapat kedinasan maupun rapat umum dengan dewan guru dan staf TU SMP Negeri 1 Cimanuk. Pendidikan karakter merupakan bagian dari pembinaan siswa SMP Negeri 1 Cimanuk yang telah diprogramkan dan dijadwalkan secara formal pada kegiatan pembinaan setiap hari jum'at pada pengajian jum'at taqwa dalam bidang keagamaan dan hari sabtu pada jam pertama dan kedua, selama 2 jam pelajaran dalam pembinaan siswa oleh masing-masing wali kelas dan kegiatan bakti sosial sekali setiap minggunya.

2. Implementasi Program Pendidikan Karakter di SMP Negeri 1 Cimanuk berupa perilaku keagamaan dari kegiatan pengajian jum'at taqwa, sebagai berikut: Pembacaan surat yasin bersama dibimbing oleh guru, Pembacaan dzikir dan tasbih bersama-sama, Tawashul yang dibimbing oleh guru dan Pembina kerohanian, pembacaan marhaba oleh siswa secara bergiliran per kelas setiap kegiatan pengajian Jum'at taqwa atau pada kegiatan keagamaan lainya, Pembacaan shalawat bersama-sama, Pembacaan do'a dipimpin oleh guru atau siswa yang ditugaskan, dan penampilan seni budaya Islam seperti group marawis dan qasidah pada waktu-waktu tertentu.

3. Program implementasi pendidikan karakter dalam perilaku keagamaan siswa yang dilaksanakan di SMP Negeri 1 Cimanuk, antara lain: membaca do'a bersama sebelum dan sesudah kegiatan belajar mengajar dipimpin oleh ketua kelas, membaca surat-surat pendek atau surat-surat pilihan 5 (lima) menit sebelum kegiatan belajar mengajar dimulai, membiasakan membaca juz'amma dan menghafalnya, serta apabila bertemu dengan guru atau siswa yang lain mengucapkan salam dalam rangka membiasakan ucapan salam. Sedangkan program implementasi pendidikan karakter dalam perilaku sosial siswa SMP Negeri 1 Cimanuk, sebagai berikut: Peduli kepada siswa yang lain/ kepada teman sekolah, Menengok teman sekolah yang sakit, Melakukan ta'ziyah apabila ada siswa/orang tua siswa yang meninggal dunia, Interaksi dan berkomunikasi dengan siswa, guru, staf TU dan kepala sekolah, Melaksanakan K 3 (Kebersihan, Keindahan dan Ketertiban) bersama-sama, Menanamkan cinta tanah air, semangat kebangsaan, disiplin, kerja sama dan tanggung jawab pada waktu pelaksanaan upacara kenaikan bendera pada setiap hari senin. 
4. Program pendidikan karakter yang diimplemantasikan di SMP Negeri 1 Cimanuk dalam membentuk perilaku sosial dan keagamaan siswa. Perilaku sosial yang suka dilakukan oleh siswa antara lain: suka mengobrol (berinteraksi dengan sesama siswa yang lain), saling membantu siswa yang lain/teman sekolah, suka menengok siswa yang sedang sakit, suka bersalam-salaman, baik dengan guru, kepala sekolah, staf TU ataupun sesama siswa, setiapsiswa melaksanakan piket sesuai dengan jadwalnya, setiap siswa bekerja sama dalam organisasi kesiswaan maupun dalam kegiatan sehari-hari di sekolah, dan ke giatan gotong-royong yang dilakukan pada hari-hari tertentu, misalnya hari sabtu pada kegiatan pembinaan yang dibimbing oleh wali kelas masing-masing.

5. Program pendidikan karakter dalam membentuk perilaku keagamaan siswa sebagai berikut: "Perilaku keagamaan yang suka dilakukan siswa SMP Negeri 1 Cimanuk", di antaranya: membaca do'a, sebelum dan sesudah kegiatan belajar mengajar, membaca do'a, sebelum dan sesudah kegiatan belajar mengajar, mengaji setiap hari Jum'at pada kegiatan pengajian Jum'at taqwa, bersalam-salaman dengan sesama siswa dan guru, serta membaca surat-surat pendek atau surat-surat pilihan.

6. Program pendidikan karakter dalam membentuk perilaku sosial sebagai berikut: "Perilaku sosial yang suka dilakukan siswa SMP Negeri 1 Cimanuk", di antaranya: siswa belajar berorganisasi, siswa bekerja sama dalam menentukan pengurus OSIS SMP Negeri 1 Cimanuk masa bakti 2015-2016, pembagian kerja dan tanggung jawab pengurus OSIS, iswa melaksanakan demokrasi dengan pemilihan langsung ketua dan wakil ketua OSIS, Penampilan siswa berpendapat di depan umum dalam menyampaikan visi dan misi organisasi OSIS, siswa berorganisasi dan bekerja sama, siswa tolong menolong dengan sesama siswa yang lainnya, siswa berorganisasi dan bekerja sama, saling membantu dalam pekerjaan organisasi siswa, kekompakan dan kebersamaan dalam berorganisasi siswa, menaati peraturan yang berlaku, serta menjalankan kewajiban siswa.

\section{CATATAN AKHIR:}

1. Djamaludin Darwis, Dinamika Pendidikan Islam: Sejarah, Ragam dan Kelembagaan, Semarang, 2006, h. 1.

2. Muchlas Samani dan Heriyanto, Konsep dan Model Pendidikan Karakter, Bandung: Rosda Karya, 2011, h. 1.

3. Kemendiknas, Desain Induk Pendidikan Karakter Kementrian Pendidikan Nasional, Jakarta,2010a, h. 1.

4. Kompas TV, Tanggal 13 Mei 2015, Siaran Kompas Petang, puku: 16.53 WIB.

5. Hasil Wawancara dengan guru PAI SMPN 1 Cimanuk, Tanggal, 15 Mei 2015.

6. Muchlas Samani dan Hariyanto, Konsep dan Model Pendidikan Karakter, Bandung: Rosda Karya, 2011, h. 42-43.

7. Kemendiknas, Desain Induk Pendidikan Karakter Kementrian pendidikan Nasional, Jakarta 2010a, h. 9. 
8. Kesuma dkk, Pendidikan Karakter: Kajian Teori dan Praktek di Sekolah, Bandung: PT. Remaja Rosda Karya, 2011, h. 11.

9. Pusat Kurikulum Balitbang Kemdiknas, Pengembangan dan Pendidikan Budaya dan Karakter Bangsa: Pedoman Sekolah, Jakarta: Puskur Balitbang, 2009, h. 9-10.

10. Juma Abdu Wamaungo dan Jarnawi Afgani Dahlan, Pendidikan Karakter di Indonesia, Banten: Wahana Cipta Mandiri, 2012, h. 9.

11. Thomas Lickona, Educating For Character: Mendidik untuk Membentuk Karakter, Bagaimana Sekolah Dapat Mengajarkan Sikap Hormat dan Tanggung Jawab, PT. Bumi Aksara, Percetakan Rosda Karya, 2013.

12. I.B Wirawan, Teori-teori Sosial dalam Tiga Paradigma: Fakta Sosial, Definisi Sosial dan Perilaku Sosial, Penerbit Kencana Prenada Media Group, 2013.

13. Moh. Dloni, Dampak Lingkungan Sosial Kemasyarakatan terhadap Perilaku Keagamaan Siswa di SMP N 2 Gabus Kabupaten Pati, Tesis, 2012.

14. Hery Nugraha, Implementasi Pendidikan Karakterdalam Pendidikan Agama Islam di SMA Negeri 3 Semarang, Tesis, 2012.

15. RA.Yusriana, Studi kasus Pemanfaatan Taman Kota Benteng Rotterdam Makasar, Jurnal Perilaku Sosial Remaja dalam Memanfaatkan Ruang Publik Perkotaan, 2013.

16. Nana Syaodih, Metodelogi Penelitian Pendidikan, Bandung: Rosda Karya, 2010. h. 54.

17. Sugiyono, Metode Penelitian Pendidikan, Pendekatan Kuantitatif, Kualitatif, dan RED, Bandung: Alfabeta, h. 300.

18. Sugiyono, Metode Penelitian Pendidikan, Pendekatan Kuantitatif, Kualitatif, dan RED, Bandung: Alfabeta h. 298.

19. Sugiyono, Metode Penelitian Pendidikan, Pendekatan Kuantitatif, Kualitatif, dan RED, Bandung: Alfabeta, h. 306.

20. Prasetya Irawan, Logika dan Prosedur Penelitian: Pengantar Teori dan Panduan Praktis Penelitian Sosial bagi Mahasiswa dan Peneliti, Jakarta: STIA-LAN, 2000, h. 100.

21. Michael Quinn Patton, Metode Evaluasi Kualitatif, Yogyakarta: Pustaka Pelajar, 2006, h. 250.

22. Sugiyono, Memahami Penelitian Kualitatif, Bandung: CV. Alfabeta, 2008, h. 89.

23. Sugiyono, Memahami Penelitian Kualitatif, Bandung: CV. Alfabeta, 2008, h. 247.

24. Winataputra dan Saripudin, Pembangunan Karakter dan Nilai-nilai Demokrasi", dalam Pendidikan Karakter: Nilai Inti bagi Upaya Pembinaan Kepribadian Bangsa, Bandung: Widya Aksara Press dan Laboratorium PKn UPI, 2011, h. 36-37.

25. Winataputra dan Saripudin, Ibid, h. 36-37.

26. Juma Abdu Wamaungo dan Jarnawi Afgani Dahlan, Pendidikan Karakter Sekolah di Indonesia, Banten: Wahana Cipta Mandiri, 2014, h. 128.

27. Hasil wawancara dengan Kepala Sekolah SMP Negeri 1 Cimanuk, pada hari sabtu, tanggal 07 November 2015, pukul : 80.00 WIB.

28. E. Koswara, Dasar-dasar Administrasi Pendidikan, Jakarta: P2LPTK, 1987, h. 42.

29. Gunarto, Implementasi Pendidikan Budi Pekerti, Jakarta: Raja Grafindo Persada, 2004, h. 22.

30. Hasil observasi pada kegiatan pengajian Jum'at Taqwa SMP Negeri 1 Cimanuk, pada tanggal, 13 November 2015, jam. $7.30 \mathrm{~s} / \mathrm{d}$ 09.00 WIB.

31. Hasil wawancara dengan guru PAI, pada tanggal, 07 November 2015.

32. Hasil wawancara dengan guru IPS SMP Negeri 1 Cimanuk pada tanggal,14 November 2015.

33. Hasil wawancara dengan siswa SMP Negeri 1 Cimanuk, pada tanggal, 14 November 2015

34. Hasil wawancara dengan siswa SMP Negeri 1 Cimanuk, pada tanggal, 14 November 2015

35. Hasil wawancara dengan siswa SMP Negeri 1 Cimanuk, pada tanggal, 17 November 2015.

36. Hasil wawancara dengan siswa SMP negeri 1 Cimanuk, pada tanggal, 18 November 2015. 
37. Pengamatan pada waktu pemilihan ketua dan wakil ketua OSIS SMP Negeri 1 Cimanuk pada tanggal, 28 Oktober 2015

38. Hasil pengamatan pada tanggal, 30 Oktober 2015.

\section{DAFTAR PUSTAKA:}

Ahmad Saebani, Beni, Metode Penelitian, Bandung: CV. Pustaka Setia, 2008.

Ahyadi, Abdul Azis, Psychologi Agama Kepribadian Muslim Pancasila, Bandung: Sinar Baru, 1991.

Arikunto, Suharsimi, Prosedur Penelitian, Suatu Teori dan Pendekatan Praktek, Jakarta: Asdi Mahasatya, 2006.

Berkowitz, M.W. dan Melinda. C. Bier, What Works in Character Education: A Research Drive Quidea for Educators, Washington DC: University of Missouri - ST. Louis.

Daradjat, Zakiyah, Pendidikan dan Kesehatan Mental, Jakarta: Bulan Bintang, 1976.

Darwis, Djamaluddin, Dinamika Pendidikan Islam: Sejarah, ragam dan Kelembagaan, Semarang, 2006.

Depdikbud, 1997, Psikologi Pendidikan, Bandung: PT. Remaja Rosda Karya.

Irawan, Prasetya, Logika dan Prosedur Penelitian: Pengantar Teori dan Panduan Praktis Penelitian Sosial bagi Mahasiswa dan Peneliti, Jakarta: STIA-LAN, 2000

Kafi, Jamaludin, Psychologi Dakwah, Jakarta: Depag, 1993.

Kartono, Kartini, Pengantar Metode Riset dan Sosial, Bandung: Manjar Maju, 1996.

Kemendikbud, Desain Induk Pendidikan Karakter Kementrian pendidikan Nasional, Jakarta, 2010a.

Kesuma, dkk, Pendidikan Karakter: Kajian Teori dan Praktek di Sekolah, Bandung: PT. Rosda Karya, 2011.

Koesoema, Doni, Pendidikan karakter Integral, diakses 7 April 2015, dari http:// www.pendidkankarakter.org/articles 003,html.

Lickona, Thomas, Educating for Character How Our School can Teach Respect and Responsibility, New York: Bantam Books.

Margono, S, Metode Penelitian Pendidikan, Jakarta: Rineka Cipta, 2000.

Moleong, Lexy, J, Metodelogi Penelitian Kualitatif, Bandung: Rosda Karya, 2009.

Patton, Michael Quinn, Metode Evaluasi Kualitatif, Yogyakarta: Pustaka Pelajar, 2006.

Pusat Kurikulum Balitbang Kemdiknas, Pengembangan dan Pendidikan Budaya dan Karakter Bangsa: Pedoman Sekolah, Jakarta: Puskur Balitbang, 2009.

Puspito, Hendro, Sosiologi Agama, Yogyakarta: Kanisius, 1984.

Rozak, Yusron, dkk, Pendidikan Agama, Jakarta: Uhamka Press, 2001.

Samani, Muchlas dan Hariyanto, Konsep dan Model Pendidikan Karakter, Bandung: Rosda Karya, 2011.

Sugiyono, Memahami Penelitian Kualitatif, Bandung: Alfabeta, 2008.

Sugiyono, Metode Penelitian Pendidikan, Pendekatan Kuantitatif, Kualitatif, dan RED, Bandung: Alfabeta, 2013.

Sugiyono, Statistik Untuk Penelitian, Bandung: CV. Alfabeta, 2007.

Sujana, Nana dan Ibrahim, Penelitian dan Penilaian, Bandung: Sinar Baru Algasindo, 2001.

Surakmad, Winarno, Pengantar Penelitian Ilmiah, Dasar, Metode dan Teknik, Bandung: Tarsito, 1989.

Syaodih, Nana, Metodelogi Penelitian Pendidikan, Bandung: Rosda Karya, 2010.

Wamaungo, Juma Abdu dan Afgani Dahlan, Jarnawi, Pendidikan Karakter di Indonesia, Banten: Wahana Cipta Mandiri, 2013 
Wibowo, Agus, Pendidikan Karakter: Strategi Membangun Karakter Bangsa Berperadaban, Yogyakarta: Pustaka Pelajar, 2012.

Zuriah, Nurul, Metodologi Penelitian Sosial dan Pendidikan, Teori - Aplikasi, Jakarta: PT. Bumi Aksara, 2006. 